\title{
Domácí úkoly z matematiky v distančním vzdělávání
}

\author{
Jan Fiala \\ Jihočeská univerzita v Českých Budějovicích, Ekonomická fakulta, Katedra aplikované \\ matematiky a informatiky
}

Problematika domácích úkolů je častým tématem odborné pedagogické literatury i obsahem diskusí odborníků z pedagogiky, psychologie i medicíny a stále více i veřejnosti. Podle jednoho pohledu jsou domácí úkoly a jejich plnění žáky snad až mimo zákon, druhým extrémem je zase evidentní přetěžování žáků i přenášení učitelské odpovědnosti za výsledky vzdělávání žáků na jejich rodiče. ${ }^{1}$ Před úkol vyvážit tyto dva přístupy byli postaveni všichni učitelé v okamžiku uzavření škol, které bylo vyhlášeno Vládou ČR v březnu 2020 s cílem zabránit dalšímu šíření epidemie koronaviru. Při zavedeném distančním vzdělávání (zvláště na ZŠ a SŠ) začalo nově hrát zásadní roli samostudium žáků. S touto formou učení se dosud setkávali žáci spíše výjimečně, někteří z nich individuálně např. při hlubším zájmu o učivo. Samostudium žákủ řídili učitelé podle našich zkušeností převážně formou zadávání domácích úkolů, které se tak staly prostředkem naplňování cílů výuky. Zásadní význam domácích úkolů potvrzují např. výsledky studie Smetáčkové (2014, s. 218), podle nichž mají domácí úkoly na celkovou úspěšnost žáků v matematice podstatný vliv. Studie rovněž upozorňuje, že pomoc rodičů se vzděláváním jejich dětí je v matematice velmi žádoucí a často nezbytná, což se naplno potvrdilo právě v době uzavření škol.

\section{Výuka v dočasně změněných podmínkách}

Příslovcem „dočasně“ optimisticky vyhlížíme na budoucí návrat standardního formátu výuky na školách, který se opírá o přímý kontakt žáků s učitelem. Interakce mezi nimi je základem efektivního učení a podle našeho názoru je jen obtížně nahraditelná. Sebelepší online výuka, která byla také součástí distanční výuky matematiky, ji nemůže podle zkušeností autora plnohodnotně, a především v dlouhodobé perspektivě nahradit.

Distanční vzdělávání, které školám a učitelům doporučilo MŠMT (2020) pro období uzavření škol, je např̀ v prostředí VŠ běžnou formou organizace

1 Podle zkušeností autora se tento jev děje dokonce i na prvním stupni ZŠ. 
vyučovacího procesu, která koresponduje s věkem studentů i úrovní jimi dosažených znalostí a psychických schopností. Náhlá potřeba uplatnit distanční výuku, tedy bezkontaktní formu vzdělávání (at' synchronní, či asynchronní), která se z velké části opírá o samostudium, v prostředí SŠ, či dokonce na ZŠ je převážně bezprecedentní. ${ }^{2}$ Jak se vyrovnat s úkolem pokračovat ve výuce svého předmětu po uzavření školy? Jak vést žáky na dálku při jejich samoučení? Jakou náhradu má učitel zvolit pro dříve běžnou kontaktní výuku u žáků mladších, jakou pro žáky vyšších ročníků? Jaké metody distančního vzdělávání zvolit? Jsou žáci samostudia vůbec schopni? Dovedou si žáci udělat vlastní výpisky $\mathrm{z}$ textu učebnice? Jak aspoň $\mathrm{v}$ uspokojivé míře procvičit učivo a jak žákům poskytovat o výsledcích sebevzdělávání objektivní zpětnou vazbu? Jak správně formativně hodnotit? Poskytla škola prostřednictvím státu pomocnou ruku učitelům v podobě dostatečné materiální a technické podpory? Byli učitelé ZŠ a SŠ vyškoleni ve formách distanční výuky? Jistě bychom doplnili mnoho dalších souvisejících otázek, které si zřejmě kladli všichni učitelé, kteří nechtěli v nových ztížených podmínkách rezignovat na své hlavní poslání; totiž přes objektivní potíže pokračovat ve výuce, upevňovat dosavadní znalosti žáků formou procvičování, jak bylo uvedeno v doporučeních učitelům na stránkách MŠMT (2020), ale i naučit žáky něco nového, samozřejmě za současného poskytování dostatečné podpory, motivace a inspirace. ${ }^{3}$

Zavést distanční výuku představovalo naléhavou výzvu směrem $\mathrm{k}$ učitelům, žákům i rodičům. Podle našeho názoru v této „zkoušce“ všichni aktéři s ohledem na odlišnosti v sociálním zázemí i přes rozdílnou vybavenost žáků prostředky ICT obstáli. Jsme přesvědčeni, že čeští učitelé novou situaci zvládli profesně velmi dobře. ${ }^{4}$ Učitelé se rychle doučili potřebné dovednosti v oblasti ICT (aplikace pro komunikaci se žáky a realizaci videokonferencí, ovládání nových programů apod.) a začali je hojně využívat při distanční výuce, byt' si jistě byli vědomi nižší efektivity své výuky, potřeby svého vyššího nasazení např. při tvorbě prezentací apod. Podle tematické zprávy ČŠI se před „krizí“ způsobenou koronavirem pouhá pětina žáků vzdělávala pomocí informačních a komunikačních technologií (Pavlas et al., 2020, s. 5). Po znovuotevření

$\overline{2}$ Na některých SŠ se organizuje distanční vzdělávání v rámci kombinovaného studia. Někteří učitelé také používají vybrané distanční formy výuky jako doplněk své prezenční výuky ve škole.

3 Připojujeme se k tomuto názoru, jak učinilo asi 90 \% všech SŠ (Pavlas et al., 2020, s. 5).

4 Opíráme se o diskuse s několika učiteli matematiky z gymnázií z různých míst ČR. Zvládnutí situace na školách potvrzuje i tematická zpráva ČŠI (Pavlas et al., 2020, s. 4). 
škol očekáváme ve výuce obecně obrat k častějšímu využívání distančních metod a forem výuky na školách a k navýšení užívání ICT ve školní výuce. Ve výuce matematiky lze takové změny jistě také očekávat.

\section{Distanční výuka (nejen matematiky)}

Distanční výukou rozumíme podle Průchy a kol. (2003, s. 46) „formu studia zprostředkovaného médii (telefon, rozhlas, televize, počítač, zvl. internet a elektronická pošta aj.)“. Distanční vzdělávání je podle týchž autorů „založeno na samostatném studiu účastníků, řízeném specializovanou institucí, bez prezenčního kontaktu studujících s vyučujícími“. Tzv. asynchronní distanční výuka se opírá především o elektronické technologie jako internet, výukové portály, výuková videa, učebnice, cvičebnice a sbírky úloh, různé aplikace (např. GeoGebra), vlastní (nejen uměleckou) tvorbu žáků, pracovní listy vytvořené samotnými učiteli, projektovou výuku aj. Naproti tomu tzv. synchronní distanční výuka využívá IT technologie, které umožňují především online přenos obrazu a zvuku, jako jsou napřs. MS Teams, Google Meet, Zoom aj.

Ve výuce matematiky podle našeho názoru asynchronní výuka na ZŠ i SŠ jednoznačně převážila nad synchronním vyučováním, přestože výsledky ČŠI v obecné rovině ukazují na opak (Pavlas et al., 2020, s. 9). ${ }^{5}$ Převahu asynchronní výuky lze podpořit více argumenty. Předně žák či učitelé často neměli dostatečné technické vybavení pro výuku synchronní, někteří žáci sice měli vhodnou IT techniku, ale neuměli s ní hned pracovat, užívaná komunikační platforma nevyhovovala všem žákům, domácí prostředí jen obtížně umožňovalo účast žáka na online výuce. Někteří žáci měli malou motivaci k sebevzdělávání, část žáků měla psychické zábrany v práci před kamerou apod. Tematická zpráva ČŠI (Pavlas et al., 2020, s. 9) také zdůraznila výhody asynchronní výuky: „Převedení běžné hodiny před kameru do online prostředí je sice technicky možné, ale didakticky velmi málo přínosné ve srovnání s některými kvalitními výukovými zdroji umístěnými na internetu, které jsou většinou časově kratší a profesionálním zpracováním pomáhají udržet pozornost žáků." Je však třeba upozornit, že pro dosažení učebního efektu takových zdrojů je nutné, aby žáci byli vybaveni takovými dovednostmi a schopnostmi, které jim umožní zmíněného potenciálu využít. Hrozí také to,

To je zřejmě způsobeno tím, že byl ve studii prezentován obecný pohled na synchronní výuku všech vyučovacích předmětů. 
že např. ne každé výukové video je svým zpracováním a náročností vhodné pro žáky daného ročníku, navíc nemusí tematicky vždy přesně korespondovat s probíraným učivem.

\section{Nová role domácích úkolů v distanční výuce}

Domácí úkol je podle Průchy a kol. (2003, s. 48) „učební nebo praktická činnost, kterou žáci vykonávají mimo vyučovací dobu, zpravidla doma. Má přímý vztah k vyučování, podporuje osvojení učiva, rozšiřuje je nebo prohlubuje. Povaha, počet a rozsah domácích úkolů nejsou na našich školách předepsány." Domácí úkoly dosud sloužily převážně k procvičování probraného učiva a jako „důležitý zdroj informací [nejen pro žáky i učitele, ale i pro rodiče] ojejich výkonu v situaci, kdy pracují samostatně bez pomoci učitele" (Kalhous \& Obst, 2002, s. 408). Někdy se domácí úkoly využívají také k zadávání dalších úkolů pro nadané žáky nebo úkolů pro žáky se speciálními vzdělávacími potřebami.

Uzavření škol však způsobilo zásadní proměnu ve způsobu vedení výuky a v oživení role domácích úkolů ve výuce. Stalo se tak i na Gymnáziu V. Nováka v Jindřichově Hradci, kde autor článku v době uzavření škol vyučoval matematiku a německý jazyk. At' zvolil ${ }^{6}$ učitel synchronní online výuku nebo asynchronní podobu výuky, či jejich kombinaci, vždy musel promyslet, jak řídit učení (samostudium) žáků. Podle našeho názoru se právě domácí úkoly staly (zvláště u asynchronních forem výuky) významným prostředníkem mezi učitelem a žáky a náhradou učitelova mluveného projevu při řádné výuce.

Každý učitel si zvolil svou platformu pro komunikaci se žáky a pro řízení jejich sebevzdělávání. My jsme při distanční výuce velmi intenzivně využívali výukové prostředí Google Classroom (viz další kapitolu), které nám efektivně pomohlo řídit jednotlivé kroky žáků v procvičování dřive probraného učiva, při jejich učení se novému učivu, v zadávání domácích úkolů i v průběžném získávání zpětné vazby o pokrocích $\mathrm{v}$ učení. $\mathrm{V}$ tomto efektivním transferu zpráv od učitele směrem $\mathrm{k}$ žákưm jim byly předávány přesné a srozumitelné pokyny, co se mají naučit, kde najdou potřebné informace, jak mají postupovat při řešení daného úkolu, kolik mají času na splnění úkolu, kde najdou pomoc při potížích s porozuměním učivu apod. Domácím úkolem tak už nebyly pouze pokyny učitele typu:

6 Některá vedení škol rozhodla o jednotné komunikační výukové platformě a nasměřovala tak učitele danou „cestou“ v organizaci vedení výuky a komunikace se žáky. Na Gymnáziu V. Nováka nebyl pro distanční výuku zvolen jednotný technologický postup. 
Vypočítej úlohu 5 na str. 56 . Zapiš informace důležité pro výpočet ze zadání, načrtni vhodný pomocný obrázek, zapiš výpočet a odpověd'.

Pokyny žáci slyšeli od učitele matematiky při školním vyučování nebo si je přečetli ve školním systému Edupage. Nově zadával učitel žákům za domácí úkoly také pokyny typu:

Jako další učivo budeme probírat obsah kruhu. Co si představiš pod obsahem kruhu? Uved' prŕíklad ze svého života, kdy potřebuješ vypočítat obsah kruhu. Přečti si v učebnici na str. 52-53 text kapitoly o výpočtu obsahu kruhu. Do sešitu si zapiš poznámky (výpisky), kde budou obrázky a popis, jak se odvodí vzorec na výpočet obsahu kruhu, vlastní vzorec pro výpočet obsahu kruhu, jednotky, ve kterých se veličina bude uvádět. Připomeň si převody jednotek obsahu. Zapiš aspoň jeden vlastní př́klad převodu jednotek obsahu. Který z matematiků se zabýval výpočtem obsahu kruhu?...

Formulace zadávaných domácích úkolů tak nově obsahují také konkrétní pokyny, kroky k učení žáků. Zvláštní pozornost je potřeba věnovat přesnosti formulací zadávaných pokynů, které musí kopírovat verbálně formulované pokyny učitele z řádné výuky ve škole.

\section{Užití Google Classroom v distanční výuce matematiky}

Převažujícím organizačním prostředkem výuky matematiky v ročnících nižšího i vyššího gymnázia se pro nás $\mathrm{v}$ nastalém období staly domácí úkoly zadávané žákům prostřednictvím aplikace Google Classroom (dále používáme český výraz „Učebna“). ${ }^{7}$ Představíme nejdůležitější ovládací prvky této celosvětově užívané aplikace v souvislosti se zadáváním domácích úkolů.

Učebna je volně šiřitelná výuková a komunikační platforma společnosti Google, která má jednoduché intuitivní ovládání a umožňuje snadné odevzdávání i efektivní a rychlou kontrolu domácích úkolů elektronickou cestou.

Úvodní stránka Učebny nabízí uživateli přehled o všech založených kurzech (obrázek 1). Na jednotlivých ikonách kurzů jsou již patrné odkazy na zadané domácí úkoly v nejbližší době. 


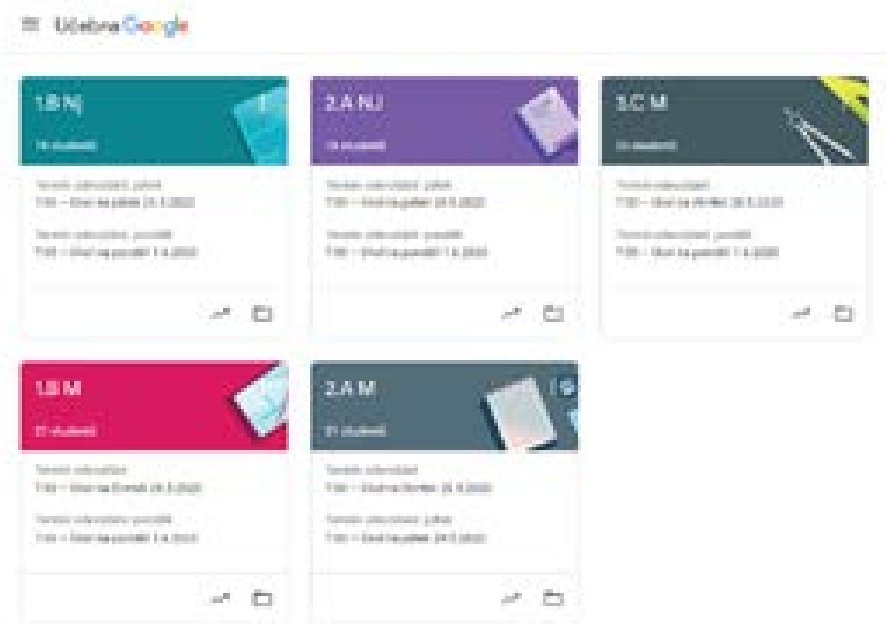

Obrázek 1. Přehled kurzů (kopii pořídil autor v aplikaci Učebna).

Dobrý přehled o všech naplánovaných úkolech a pokynech získá učitel v Kalendáři (obrázek 2).

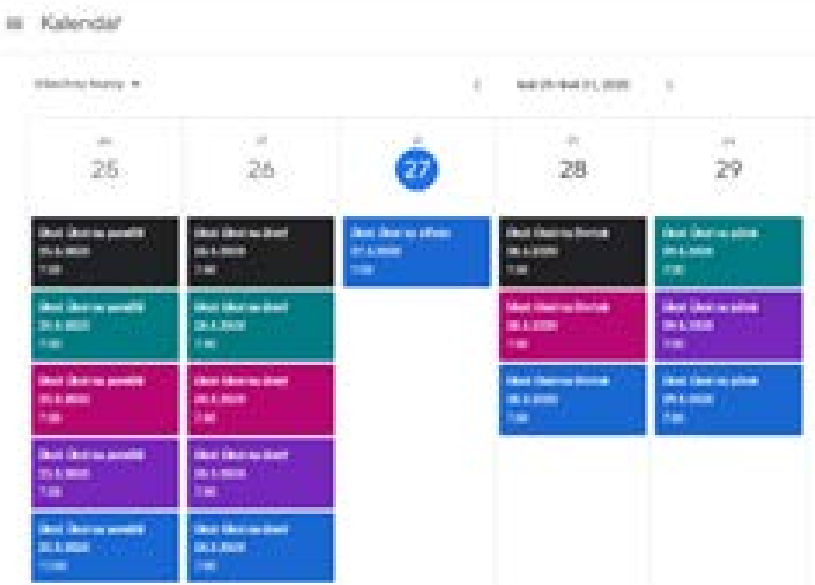

Obrázek 2. Výřez z Kalendáře v aplikaci Učebna (kopii pořídil autor v aplikaci Učebna). 
Úvodní stránka každého kurzu nabízí čtyři volitelná prostředí: Stream, Práce v kurzu, Lidé a Hodnocení.

V tzv. Streamu jsou viditelné všechny zadané úkoly a všechna další sdělení učitele pro žáky. Právě zde lze uveřejňovat např. odkazy na videa s návody na ovládání aplikace, sdílet prezentace či uveřejňovat jiná sdělení k organizaci výuky, informace $\mathrm{k}$ hodnocení apod. Žáci mají možnost jednotlivá sdělení učitele komentovat.

Pohled na všechny zadané úkoly umožňuje učiteli i žákům sekce Práce v kurzu (obrázek 3).

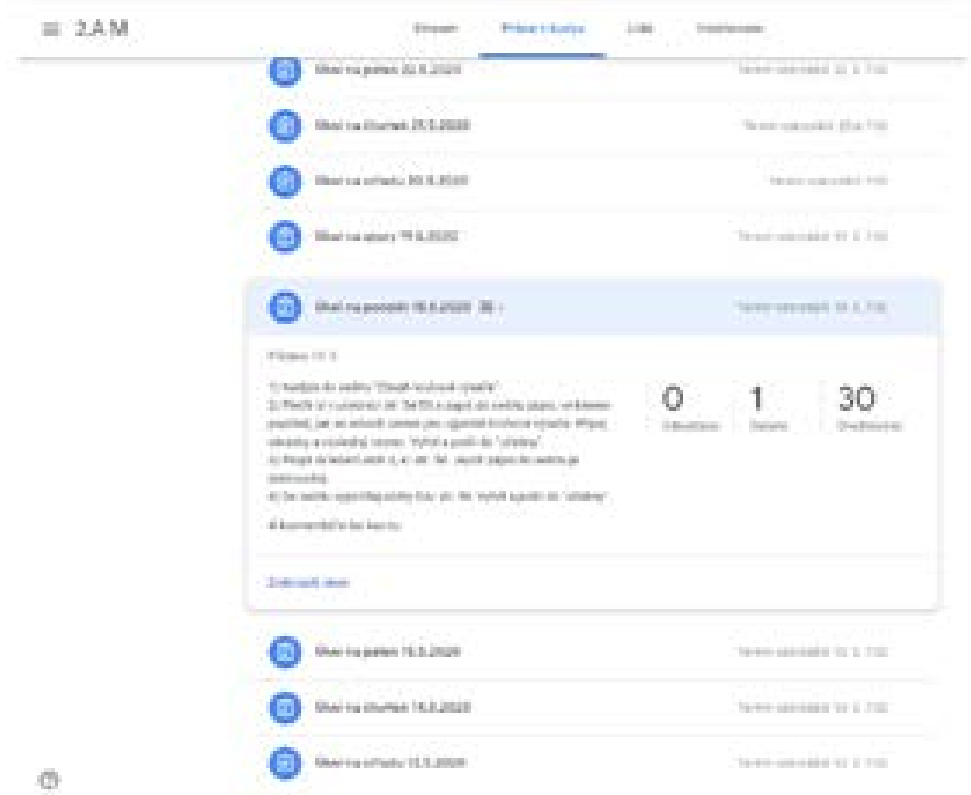

Obrázek 3. Výřez z kopie stránky s domácími úkoly v sekundě víceletého gymnázia (kopii pořídil autor v aplikaci Učebna).

Dobu pro splnění každého úkolu je možné časově omezit. Každý úkol může být bodově hodnocen. Na obrázku 4 je ukázka zadání jednoho domácího 
úkolu pro žáky sekundy. Číslo 30 označuje počet ohodnocených domácích úkolů (ve třídě je celkem 31 žáků), které učitel žákům odevzdal zpět ke kontrole, k nahlédnutí a opravě chyb. Jednomu žákovi byl úkol zadán, ten jej však dosud neodevzdal.

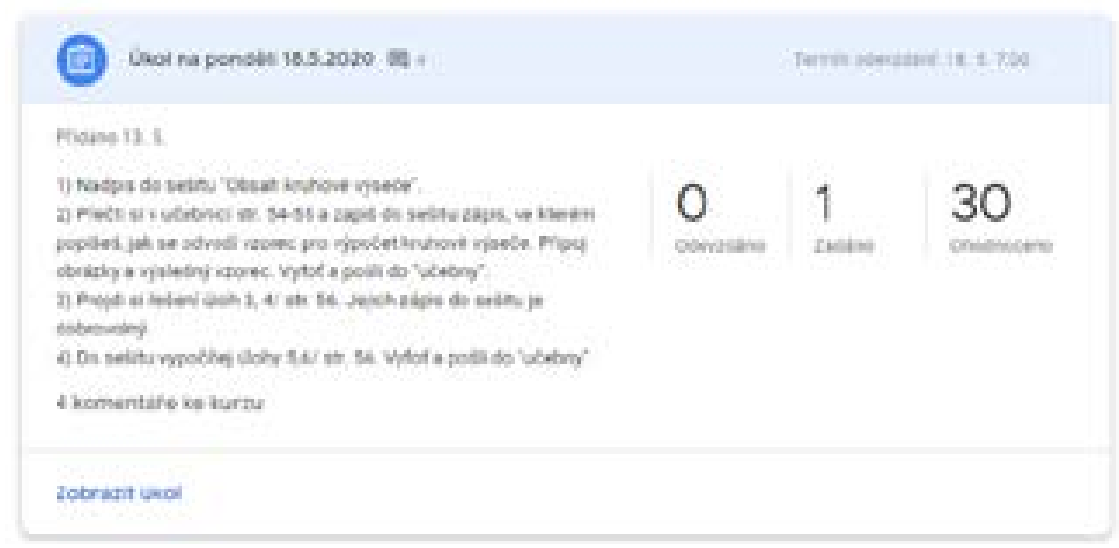

Obrázek 4. Detail obrázku $1 \mathrm{~s}$ úplným zadáním jednoho úkolu pro ročník sekundy (kopii pořídil autor v aplikaci Učebna).

Na obrázku 5 je kopie stránky s odevzdaným úkolem jednoho žáka, jak jej uvidí učitel na své obrazovce. V pravé části obrázku 5 jsou ikony, pod nimiž se skrývají další přiložené soubory (fotokopie, skeny) s domácími úkoly. Ty je možné zobrazit v samostatném oknu. Vybraný dokument (fotokopii) je v Učebně možné zvětšit pro snazší čtení a opatřit komentáři. V pravé části obrázku 5 je také vidět, že učitel udělil žákovi za domácí úkol maximální počet bodů. 


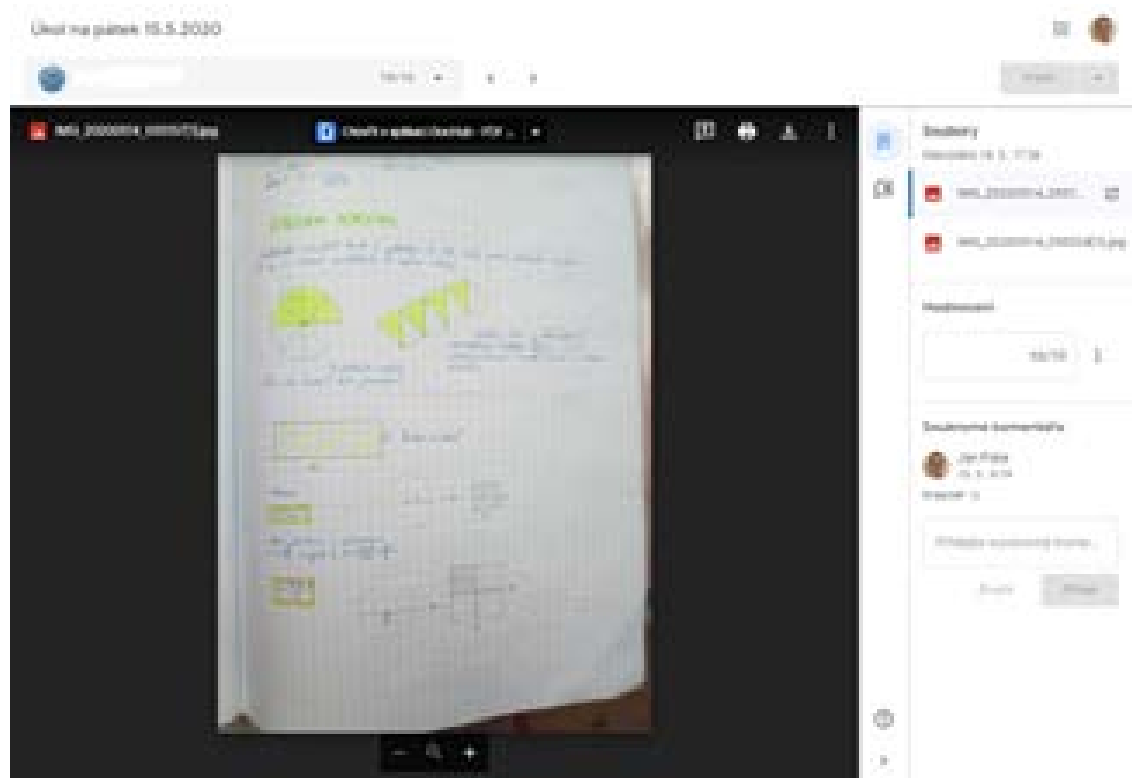

Obrázek 5. Výřez z kopie stránky s odevzdaným úkolem od žákyně sekundy k učivu obsah kruhu (kopii pořídil autor v aplikaci Učebna).

Učitel může chyby v úkolu v konkrétním místě vyznačit a opatřit je svým komentářem. Každý žák má možnost chyby $\mathrm{v}$ domácím úkolu podle pokynů opravit a úkol učiteli odevzdat znovu. Systém Učebny ukládá všechny domácí úkoly na disk učitelova počítače a je tak možné, aby se rodiče či vedení školy seznámili s průběhem odevzdávání domácích úkolů i s úrovní jejich vypracování u konkrétního žáka. Rovněž se uchovávají vedené konverzace (obrázek 6) mezi žákem a učitelem, které jsou dokladem individuálního přístupu učitele k obtížím žáků při řešení matematických úloh.

V části Hodnocení informuje Učebna žáka, jeho rodiče i učitele o celkovém hodnocení, které je vyjádřeno $\mathrm{v}$ procentech. Některé úkoly nemusí být bodovány. 
$22,4+4$

Debry cet onlouvan se ie odevgdivin posst. Chol jeem na goode ciansioom pletiedla Rownsy bych chiela doght

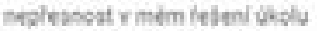
17 is hokud je zadana urcni secna, tak je ik ni novnobetind poute jedna techa inotom ms Lhol jen jedas pelenil poinud nevi uskena sekso na pleintm mistet. posom milte bit nekooeknt mocho lelenk feving ath

Jan figla

$22+14: 44$

Lnets. tvym uraham moc

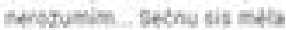
noriverat libovilht Pak jwas gravet ove heseni, muldes novit

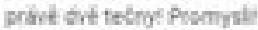
Marnaly si for $y$ if

124,1118

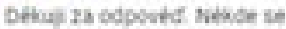
musela ntin ehyba Jeine se nad tin zanyilim Dethos

Jan Fivls

21. 2.135

Opcar ai to a pod knows Jf

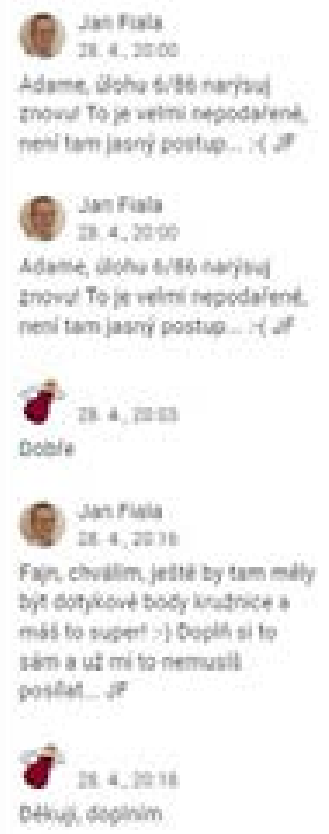

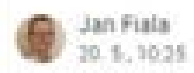

Oprar brosim podle komentale povebulesa pomost s iedenim. nopis:s



Dobry den, omlowim se, y releni ckoll jsem se soleti.

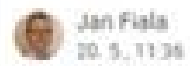

Feme, nemuail se omilowat o he nejoe. jen sa to opier a post mowa dam ti plnj pocet boos $\rightarrow$

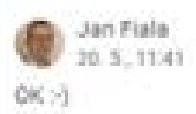

Obrázek 6. Ukázky konverzace žáka a učitele u odevzdaného úkolu (kopii pořídil autor v aplikaci Učebna).

\section{Vlastní pojetí distanční výuky matematiky}

V době uzavření škol vyučoval autor příspěvku na Gymnáziu V. Nováka v Jindřichově Hradci distanční formou matematiku žáky ve 2. ročníku osmiletého a v 1. a 3. ročníku čtyřletého gymnázia. Podle dostupných informací měli všichni žáci př́stup na internet a byli vybaveni potřebnou IT technikou. 
Za hlavní vyučovací a učební prostředek byly vzhledem k rychlému přechodu do distančního vzdělávání žáků ZŠ a SŠ zvoleny učebnice matematiky, ${ }^{8}$ které považujeme za osvědčenou didaktickou pomůcku a za někdy opomíjený zdroj kvalitních informací, které jsou vhodně přizpůsobeny učebním potřebám žáků. Výhodou bylo, že každý žák (2. ročníku osmiletého gymnázia) měl učebnici doma k dispozici. Žáci sekundy učebnice již dříve využívali ve škole při běžné výuce matematiky (při výkladu nového učiva, k vysvětlování, při procvičování učiva a řešili z nich také domácí úkoly), a tak práce s nimi nebyla pro žáky nic nového.

Jako doprovodné materiály byly především žákům vyššího gymnázia zprostředkovány (sdíleny přes disk Google) tzv. soubory učebních úloh (dohodli jsme se na užívání zkratky SUU ${ }^{9} \mathrm{~s}$ řešenými i neřešenými matematickými úlohami připravenými učitelem, z nichž žáci také kromě učebnic či sbírek úloh čerpali matematické úlohy k procvičování učiva. Mladší i starší žáci dále využívali odkazy na výuková videa, ${ }^{10}$ cvičebnice, vybrané webové stránky apod. Klasickou školní tabuli nahradily při vysvětlování nového učiva fázové obrázky a matematické zápisy v učitelových prezentacích. Dále jsme využívali prezentace nebo prezentace s nahraným zvukovým komentářem učitele.

Kromě výše zmíněných asynchronních forem byly při distanční výuce matematiky využívány také metody synchronní, především jsme pořádali videokonference pomocí aplikace Google Meet. Setkání se žáky v podobě videokonferencí se zaměřily zvláště na vysvětlování nového učiva během prezentace a následnou diskusi se žáky, při níž učitel zodpověděl dotazy žáků. Většinou byly videokonference organizovány pro celou třídu v dopoledních hodinách, občas byly naplánovány pro setkání učitele jen s jedním žákem.

8 V sekundě víceletého gymnázia žáci používali dvě učebnice: Herman, J., Chrápavá, V., Jančovičová, E., \& Šimša, J. (1995). Matematika: hranoly. Praha: Prometheus.; Herman, J., Chrápavá, V., Jančovičová, E., \& Šimša, J. (1996). Matematika: kruhy a válce. Praha: Prometheus. Na čtyřletém gymnáziu byly žákům doporučeny učebnice:

Charvát, J., Zhouf, J., \& Boček, L. (1999). Matematika pro gymnázia: rovnice a nerovnice. Praha: Prometheus.

Calda, E., \& Dupač, V. (1993). Matematika pro gymnázia: kombinatorika, pravděpodobnost a statistika. Praha: Prometheus.

9 Soubor učebních úloh (SUU) v našem pojetí je číslovaný seznam matematických učebních úloh $\mathrm{k}$ danému učivu, a to různého typu i náročnosti (většinou s uvedenými výsledky).

10 Z velkého množství dostupných výukových videí na internetu žáci nejčastěji čerpali informace z videí na www.isibalo.cz. K některým videím poskytl učitel doprovodný komentár. 
Domácí úkoly, o které jsme asynchronní výuku opřeli, jsme žákům zadávali prostřednictvím Učebny vždy v ranních hodinách (7.00-9.00). Žáci měli úkoly splnit během dne a odevzdat je učiteli zpět ke kontrole vždy do 7.00 hodin následujícího dne nebo dne, na kdy by připadla další hodina matem tiky podle stálého rozvrhu. Nedbale vypracované úkoly nebo úkoly s chybou učitel žákům vracel, někdy i opakovaně, až se nakonec podařilo chyby napravit. Tak dosáhli nakonec téměř všichni žáci úplného bodového hodnocení. ${ }^{11}$ Učitel často připojoval k vypracovaným úkolům i pochvaly za práci žáků za účelem jejich pozitivní motivace.

\section{Pohled učitele na distanční výuku}

Výše popsaný způsob vedení výuky v podobě systematického zadávání domácích úkolů, které navíc obsahovaly také pokyny k učení, prostřednictvím Učebny se ukázal jako velmi efektivní. Žákům nedělaly pokyny učitele žádné problémy a úkoly plnili velmi dobře co do množství i kvality. Rovněž si učitel zlepšil své pedagogické dovednosti, hlavně v přesnosti formulace domácích úkolů. Nový obsah zadávaných úkolů s sebou ale přinesl i některé dávno známé problémy související s učením, např. potíže s porozuměním při čtení matematického textu. Díky zařazení ICT technologií si žáci i učitel sekundárně zdokonalili své dovednosti a znalosti také v této oblasti.

Učitelova důsledná kontrola plnění domácích úkolů ukázala na ty žáky, kteří s obtížemi plnili zadávané domácí úkoly i při běžné výuce ve škole. Především tito žáci se museli postupně naučit odpovědně, včas a v požadované kvalitě plnit své povinnosti při distančním vzdělávání (včas odevzdávat domácí úkoly, reagovat na výzvy, komentáře a upozornění učitele aj.). Nebylo proto výjimkou, že učitel i opakovaně požadoval od žáků opravu domácího úkolu, jeho doplnění či vylepšení. Někteří rodiče dali učiteli zpětnou vazbu a hodnotili takový prrístup kladně. ${ }^{12}$ Práce učitele s domácími úkoly pomocí aplikace Učebna byla ve srovnání s postupy kontroly domácích úkolů při běžné výuce výrazně efektivnější, pro učitele ovšem velice časově i psychicky náročná. Jen obtížně si dovedeme představit dlouhodobou takovou realizaci kontroly domácích úkolů.

Ožehavým tématem bylo množství zadávaných úkolů. Proto jsme velmi pečlivě uvažovali o tom, $\mathrm{v}$ jakém množství a $\mathrm{v}$ jaké náročnosti budeme úkoly

11 Ne všechny domácí úkoly byly hodnoceny bodováním.

12 Opíráme se o rozhovor s několika rodiči vyučovaných žáků. 
v rámci distančního vzdělávání žákům zadávat. Zvolené množství úkolů odpovídalo zhruba třem čtvrtinám všech úkolů splněných během řádné výuky. Přitom úkoly jsme žákům zadávali vždy v předstihu i několika dnů a pouze na pracovní dny, kdy měli žáci mít hodinu matematiky podle řádného rozvrhu. Zaregistrovali jsme reakci jediného rodiče, který označil takové množství zadávaných úkolů za přehnané.

Přístup žáků k plnění domácích úkolů byl značně individuální. Někteří žáci odevzdali vypracovaný úkol ke kontrole velice rychle (často v řádu několika minut po zadání učitelem). Naprostá většina žáků zvládla úkol odevzdat v termínu do 7.00 následujícího dne. Jen výjimečně některým žákům trvalo splnění zadaného úkolu nad časový limit. Tito žáci však podle vyjádření třídní učitelky neplnili úkoly (vůbec či včas) ani v ostatních vyučovacích předmětech. Přitom tito žáci podle svých slov na úkol často spíše jen zapomněli nebo jim nefungovala správně technika apod. Proto jednoznačně hodnotíme přístup k plnění domácích úkolů většiny žáků nižšího gymnázia i u převážné většiny studentů vyšších ročníků gymnázia za velmi zodpovědný, přestože by se daly najít rozdíly v kvalitě provedení i správnosti řešení úkolů.

Mnoho zkušeností získal učitel při zadáváním pokynů k výuce matematiky prostřednictvím Učebny. Zadání úkolů bylo potřeba formulovat velice přesně, výstižně a formálně přehledně, tak jak je to běžné v řádné výuce. Např. formulace Zpracuj si výpisky z textu na str. 52-53 byla obsahově nedostačující, a tedy nefunkční. Osvědčilo se nám vždy ještě podrobně žákům popsat, na jaké otázky musí výpisky žáků z učebnice odpovědět či jaké pojmy nebo formule musí být do výpisků zahrnuty. Pak žáci správně plnili všechny zadané domácí úkoly.

Z analýzy obsahových chyb, které se objevovaly při řešení matematických úloh při distanční výuce, vyplývá, že mají někteř́ žáci problémy s porozuměním zadání matematické úlohy (zvláště mladší žáci, kteří někdy vypočítali něco zcela jiného, než bylo úkolem). Jindy žáci vypočítali pouze dílčí výsledek, který však nebyl odpovědí na otázku ze zadání. Potvrdilo se nám, že čtení s porozuměním zůstává (především u žáků mladšího školního věku) ve školním vzdělávání i nadále značným problémem a doporučujeme vyčlenit v řádné výuce i na tento způsob práce potřebný čas a dovednosti tohoto typu se žáky trénovat. Na druhou stranu lze konstatovat, že četnost těchto jevů byla srovnatelná $s$ výskytem podobných problémů při řádné výuce ve škole. Následnou analýzou vzniklé chyby učitel žáka pomocí komentářù ke správnému výsledku dovedl. 
S ovládáním aplikace Učebna měli někteří žáci zpočátku problémy. Podle vyjádření některých $\mathrm{z}$ nich bylo obtížné zorientovat se $\mathrm{v}$ novém prostředí. Postupně se však nakonec všichni žáci naučili ovládat všechny používané prvky aplikace. Je tak evidentní, že vzniklé změny ve vedení výuky sekundárně přispěly k rozvoji informační (počítačové) gramotnosti žáků, na kterou je v současné době právem kladen velký důraz. Zásadní rozdíly v úrovni dovedností ovládat a užívat počítačové technologie jsme mezi jednotlivými ročníky (sekundáni, žáci 1. a 3. ročníku vyššího gymnázia) nepozorovali; i některým starším žákům trval nácvik ovládání technologií překvapivě dlouhou dobu.

Synchronně vedenou výuku matematiky ve formě videokonference nemůžeme na základě našich zkušeností označit za nezbytnou součást distanční výuky. Podle našeho názoru online vysvětlování učiva pomohlo především těm žákům, kteří mají problémy s porozuměním psanému textu. Většina žáků by se bez online hodin obešla. Hlavním problémem v synchronní výuce totiž bylo, že se jí nikdy nezúčastnili všichni žáci, kteří byli na setkání pozváni, ani přesto, že se tak stalo $v$ dostatečném předstihu. Účast žáků byla většinou silně podprůměrná. Výuková hodina tzv. „online“ také neznamená, že je žák skutečně aktivně zapojený do výuky. Žáci většinou vypnuli přenos obrazu i zvuku a učitel často jen obtížně vybízel žáky k vyšší aktivitě nebo aspoň k pouhé odpovědi na položený dotaz. Online výuka se nám tedy jeví jako nedostatečně kontaktní. Rovněž se potvrdilo, že synchronní hodiny se musely často výrazně zkrátit, nebot' žáci neudrželi potřebnou pozornost a soustředění. Online výuku delší než 30 minut proto nemůžeme doporučit. Podle třídních učitelů a žáků nemůže mít třída během celého dopoledne blok více synchronních hodin za sebou a nelze tak „překlopit“ celý stálý rozvrh ročníku do online výuky. Uvažuje-li se o nastavení pravidel pro distanční výuku na ZŠ a SŠ, mělo by se také k této věci přihlédnout stejnou vahou jako k rozdílnému technickému vybavení žáků a učitelů $v$ domácím prostředí. $Z$ výše uvedeného soudíme, že jsme naplnili doporučení MŠMT (2020) k distanční výuce, podle kterého „je zapotřebí, aby učitelé přistupovali k zadávání úkolů citlivě a měli na zřeteli možnosti konkrétních žáků. Pro zdárný průběh vzdělávání na dálku je potřeba udržovat zpětnou vazbu mezi učitelem a žákem/rodiči, co do množství i obtížnosti učiva."

V souladu s Vyhláškou o hodnocení výsledků vzdělávání žáků ve druhém pololetí školního roku 2019/2020 vydané 27. 4. 2020 MŠMT ČR ${ }^{13}$ jsme se

13 Dostupné z http://www.msmt.cz/file/52751/. 
zaměřili na dosažení spravedlivého hodnocení každého žáka a respektovali jeho individuální podmínky na domácí učení. Zvolený systém Učebna umožnil tato doporučení zcela naplnit. Připojujeme se také k názoru MŠMT, že je vhodné v nastalé situaci více podporovat nácvik samostatnosti žáků při plánování a organizaci svého vzdělávání a při jejich hodnocení se zaměřit hlavně na hodnocení formativní. Kromě slovního formativní hodnocení jsme tedy využili „tréninkové“ online testy (hodnocené procentuální úspěšností) a především práci s chybou. Ta probíhala při naší výuce na dálku tak, že odevzdaný domácí úkol (v podobě fotokopie) učitel opravil vyznačením chyb pomocí tzv. komentářů a $\mathrm{k}$ tomu ještě často přidal nějakou zprávu, ve které bylo upřesnění a zdůvodnění uděleného stupně hodnocení (např. Výborně! Krásné! Skvělé zpracování! OK apod.). Rozhodně se však přikláníme k jakémukoliv hodnocení zadávaných úkolů (známkou, bodově, slovní hodnocení aj.), nebot' jak radí Petty, „učitel musí každý zadaný úkol vidět, překontrolovat nebo oznámkovat, jinak nebudou někteř́ žáci úkoly vypracovávat" (Petty, 1996, s. 264). Některé zadané úkoly (např. při práci s textem či s prezentací a z něj, resp. z ní plynoucí tvorba výpisků do školního sešitu) byly podle předem známých kritérií hodnoceny body. Žák měl po „vrácení“ domácího úkolu možnost číst učitelovy komentáře s doporučeními a slovním hodnocením výsledků jeho práce, zjistit počet dosažených bodů, úkol případně opravit a odevzdat k nové kontrole. Aplikace Učebna nám umožnila efektivně řešit prosby žáků o vysvětlení učiva, vyhovět žádostem o radu k postupu řešení úlohy či jiné záležitosti, a to kdykoliv během dne, což u běžné výuky po skončení vyučování většinou neprobíhá.

V Učebně má žák v části „Hodnocení“ možnost přesně sledovat svou celkovou úspěšnost při plnění úkolů vyjádřenou procenty. Například u třídy 31 žáků sekundy se úspěšnost $\mathrm{v}$ plnění domácích úkolů $\mathrm{v}$ předmětu matematika pohybovala od 64 do $100 \%$. I tato forma zpětné vazby však zůstává pouze informativní (pro žáky i rodiče) a má spíše motivační povahu. V několika případech se žáci dobrovolně přihlásili na tvorbu prezentací na dané téma. Tento úkol byl již hodnocen známkou. $\mathrm{Z}$ online diskusí s některými žáky vyplývá, že jim chybí běžný „známkový“ způsob hodnocení obecně. Někteř́ žáci by souhlasili i s hodnocením domácích úkolů. Dle zkušenosti autora z 20leté učitelské praxe s tím vyjadřují souhlas prakticky všichni rodiče - na rozdíl od vedení škol, která se hodnocení domácích úkolů, aspoň v našem případě, velmi brání. 
Závěrem zmíníme i jednu negativní zkušenost z distanční výuky matematiky: Z řešení některých obtížnějších úloh zvláště staršími žáky bylo patrné opisování úkolu od spolužáka. Vodítkem byla většinou chyba, které se šikovný žák dopustil a kterou pak mnoho jeho spolužáků bez váhání opsalo. Opisující žáci také často natolik zkracovali zápis spolužákova řešení, že se pro svou lenost vlastně prozradili. Problému opisování lze čelit jen velmi obtížně. Ani rozdílné zadání domácího úkolu pro každého žáka by zřejmě nepomohlo, a navíc by bylo pro učitele co do množství přípravy nemyslitelné. Znovu jsme si tak uvědomili nenahraditelnost kontaktní výuky vedené ve školním prostředí pro objektivní hodnocení skutečných znalostí a dovedností žáků.

\section{Pohled žáků na distanční vzdělávání v matematice}

Předmětem našeho zájmu se staly i názory a postoje žáků na distanční vzdělávání v matematice. Zvláštní pozornost jsme věnovali domácím úkolům $\mathrm{z}$ matematiky $\mathrm{v}$ převážně asynchronně vedené výuce. Žáci se $\mathrm{k}$ zadávaným domácím úkolům a pokynům, stejně jako k porozumění učivu, využívání učebnic, množství zadávaných úkolů apod. měli možnost vyjádřit prostřednictvím aplikace Učebna v krátkém elektronickém dotazníku (anketě) s celkem 24 otázkami koncem května 2020. Elektronický anonymní dotazník zpracovaný v Google Forms vyplnilo celkem 71 z celkem 81 oslovených žáků tř́d Gymnázia V. Nováka v Jindřichově Hradci. Byli to žáci sekundy (11-12 let), žáci prvního ročníku (16 let) a žáci třetího ročníku vyššího gymnázia (18-19 let). Žáci se vyjadřovali většinou výběrem vhodné odpovědi v převážně uzavřených položkách. Pro další text jsme vybrali z dotazníku jen některé otázky, odpovědi na zbylé otázky jsme shrnuli do níže prezentovaných tezí. Některá podstatná zjištění dále komentujeme.

Otázka: Jak ti vyhovuje učení matematice doma?

Asi 50 \% žáků uvedlo, že jim výuka doma spíše vyhovuje. Přibližně 39 \% žáků uvedlo, že jim výuka matematiky doma spíše nevyhovuje a chtěli by radši namísto toho chodit do školy. Necelým 5 \% žáků výuka doma vůbec nevyhovuje, mnohem raději bych chodili do školy. 6 \% žáků výuka matematiky doma natolik vyhovuje, že vůbec nepocitují potřebu chodit do školy. 
Otázka: Jak se ti podle tebe daří učit se matematiku doma?

Dohromady $43 \%$ žáků si myslí, že se doma naučili v matematice mnohem méně nebo spíše méně než ve škole. 41 \% žáků uvádí, že se naučili matematiku zhruba ve stejné míře jako ve škole. Asi 16 \% žáků se domnívá, že se naučili doma spíše více, nebo dokonce mnohem více než ve škole. ${ }^{14}$

Otázka: Je podle tebe správné, aby bylo předepsané učivo z matematiky probráno a procvičeno do konce tohoto školního roku?

67 \% žáků souhlasí s tím, aby se předepsané učivo podle ŠVP probralo ještě $\mathrm{v}$ tomto školním roce a nebylo tak potřeba $\mathrm{v}$ dalším školním roce dohánět učivo.

Další tři otázky se týkaly spokojenosti žáků s aplikací Učebna. 36 \% žáků se aplikace „líbí“, dokonce 64 \% vybralo možnost „velmi líbí“. Nikdo neuvedl žádné negativní hodnocení. Žáci se dále vyjádřili k funkčnosti a praktičnosti této komunikační platformy. Na stupnici se čtyřmi volitelnými možnostmi od 1 (vůbec není funkční a praktická) do 4 (velmi funkční a praktická) zvolilo $42 \%$ žáků hodnotu 3 a zbylých $55 \%$ dokonce hodnotu 4. Ujišt'uje nás to $v$ tom, že jsme aplikaci Učebna jako komunikační a výukovou platformu zvolili správně. Učitele rovněž potěšil převažující názor žáků ( $50 \%)$, že by se Učebna mohla pro domácí úkoly využívat i příští školní rok. Dalších 22 \% žáků by další používání Učebny k odevzdávání úkolů z matematiky dokonce rozhodně přivítalo. Naproti tomu $20 \%$ žáků označilo Učebnu za ne úplně ideální a pouhých 8 \% za nevhodnou pro odevzdávání úkolů v matematice.

Zásadní roli při práci s chybou hrají v Učebně komentáře učitele. 91 \% žáků si umí komentáře učitele zobrazit, což je však podle našich zkušeností v rozporu s vyjádřeními některých žáků. Řada z nich spíše nechce přiznat, že mají se zobrazením komentářů potíže. ${ }^{15}$ Komentáře učitele považuje $58 \%$ žáků za velmi užitečné nebo spíše užitečné při opravě chyb v domácích úkolech, 30 \% je považuje za spíše neužitečné a podle 12 \% žáků komentáře při opravě chyb nepomáhají. 68 \% žáků přiznalo, že neví, že mohou označit komentáře za tzv. vyřízené, což znamená, že je učitel informován o nápravě chyby žákem. Asi pětina žáků (odhadujeme, že jde o žáky spíše z vyššího gymnázia) tuto možnost využívá, což můžeme potvrdit.

14 Jde o subjektivní posouzení žáků o vlastních znalostech a dovednostech v matematice. V dotazníku jsme nezjištovali rozdíly v efektivitě výuky matematiky doma a ve škole.

15 Někdy jsou tyto potíže způsobené technickou závadou či problémy se softwarem. 
V oblasti plnění domácích úkolů z matematiky oceňuje 95 \% žáků to, že si mohou splnit domácí úkol kdykoliv během dne. Je tedy správné, aby učitel dobu na vypracování úkolů neomezoval např. na dopolední hodiny. $34 \%$ žáků splní úkol z matematiky během dopoledne, $19 \%$ během odpoledne, $45 \%$ během večera, mizivý zbytek žáků odevzdá domácí úkol až těsně před odevzdáním, tj. v našem případě před 7.00 ráno. Povzbudivé výsledky přinesly rovněž odpovědi na otázku, jak dlouho trvá žákům vypracovat domácí úkol z matematiky při distanční výuce. 12 \% žáků pracuje na úkolu maximálně 20 minut, $45 \%$ maximálně 40 minut (což odpovídá zhruba délce vyučovací hodiny ve škole), $32 \%$ do 1 hodiny a $11 \%$ do 2 hodin. Žádnému žákovi netrvá vypracovat úkol více než 2 hodiny. Současně 55 \% žáků uvedlo, že má velmi mnoho času či přiměřeně dost času na vypracování domácího úkolu, je-li úkol zadán do 7.00 hodin následujícího dne. 11 \% žáků nemá na vypracování úkolu dost času, což zřejmě souvisí i množstvím dalších zadávaných úkolů z jiných vyučovacích předmětů.

Přiměřené množství zadávaných úkolů při distanční výuce matematiky potvrzují další data, jak je patrné z grafu na obrázku 7 . Výsledky jednoznačně ukazují, že množství zadávaných úkolů v matematice bylo podle názoru žáků zvoleno správně.

\section{Kolik je podle tebe zadávaných domácich úkolũ z matematiky?}
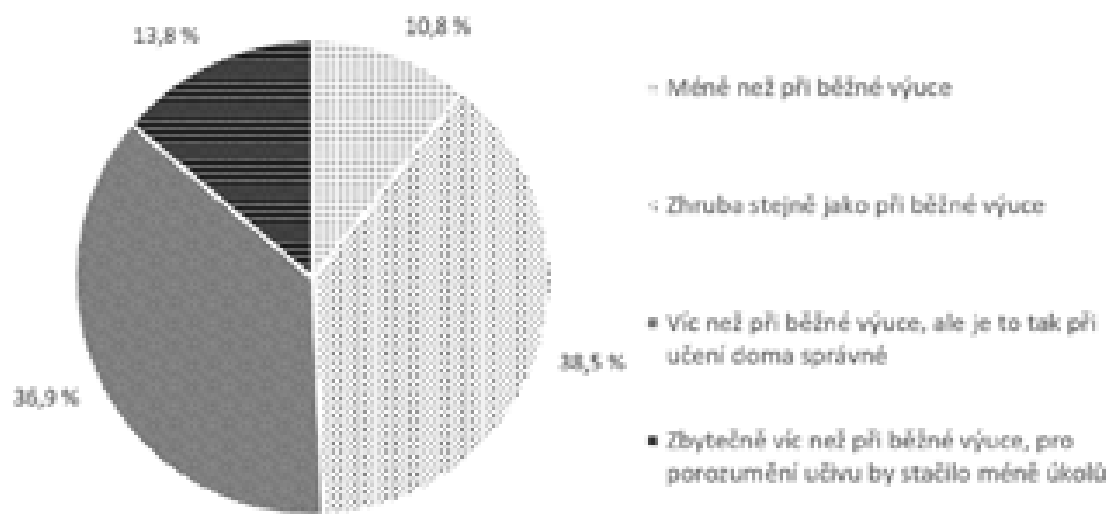

Obrázek 7. Graf s výsledky dotazování žáků na množství zadávaných domácích úkolů z matematiky. 
Celkem 88 \% žáků si myslí, že učitel zadává domácí úkoly jasně, srozumitelně a přesně nebo tomu tak většinou je. Ptali jsme se žáků také na to, zda si před odevzdáním úkolu zkontrolují své výsledky podle učebnice matematiky. 39 \% žáků si výsledek vždy před odevzdáním úkolu zkontroluje, 20 \% jen občas, 29 \% spíše výjimečně a 12 \% žáků si výsledek nikdy nezkontroluje.

Otázka: Jak ti pomáhá učebnice matematiky při porozumění novému učivu ? $^{16}$ $31 \%$ žákư $^{17}$ učebnici nemá a nepoužívá ji, $22 \%$ učebnici používá občas a vždy jim podle jejich slov učebnice pomůže v porozumění učivu a $20 \%$ žáků využívá ke studiu jinou učebnici, než doporučil učitel. Zjištění o skutečném př́nosu učebnic k porozumění učivu matematiky a o obecné roli učebnic $\mathrm{v}$ distanční výuce matematiky by si vyžádalo samostatné výzkumné šetření. Data uvedená výše potvrzují, že žáci nižšího gymnázia pracují s učebnicí matematiky mnohem více než žáci vyššího gymnázia.

Otázka: Co ti dále pomáhá, když se doma učís matematiku ${ }^{18}$

65 \% žáků vybralo prezentace od svého učitele, 37 \% zvolilo soubory učebních úloh od svého učitele, $11 \%$ využívá prezentace $\mathrm{z}$ internetu od jiných autorů, 54 \% žáků čerpá z výukových videí na internetu, 30 \% žáků se učí na různých vzdělávacích serverech.

94 \% žáků souhlasilo s tím, že má možnost v případě neporozumění učivu obrátit se na svého učitele s prosbou o radu. 60 \% žáků této možnosti také využilo, což se zkušenostmi učitele z výuky na dálku nekoresponduje. Přestože se řada žáků učitele dotazovala, nebylo jich podle našeho odhadu mnoho. Proto jsme se v této souvislosti žáků také ptali, proč se na svého učitele matematiky s prosbou o pomoc spíše neobrací. 55 \% žáků zvolilo odpověd', že chce úlohu vždy raději spočítat samo, 23 \% žáků se stydí zeptat, 29 \% nechce učitele obtěžovat a $9 \%$ nemá čas se ho ptát. ${ }^{19}$ Kdo tedy kromě učitele žákům s učením matematice $\mathrm{v}$ domácím prostředí pomáhá? 32 \% žáků se učí pouze samo, 79 \% o radu při učení prosí svého spolužáka, 25 \% svého kamaráda ze školy (z jiné třídy), v 29 \% pomáhají žákům s učením rodiče, prarodiče pak v $9 \%$.

\footnotetext{
Žáci mohli vybrat více odpovědí.

Jde spíše o studenty vyššího gymnázia, na nižším gymnáziu učebnici žáci dostávají.

Žáci mohli vybrat více odpovědí.

Žáci mohli vybrat více odpovědí.
} 
Otázka: Jak ti při domácím učení pomáhá v matematice výklad učitele při online hodině (Google Meet, MS Teams, Zoom aj.) nebo při okomentované prezentaci ${ }^{20}$ ?

51 \% žáků výklad učitele při online hodině potřebuje a pomůže jim při porozumění novému učivu, $42 \%$ si výklad sice poslechne, ale nepotřebuje ho, 8 \% žáků výklad při online hodině vůbec nepotřebuje a považuje ho za nadbytečný. Nikdo z žáků neuvedl, že by bez online hodiny látce neporozuměl.

Otázka: Do jaké míry jsi podle tebe porozuměl(a) novému učivu v matematice při učení doma?

8 \% žáků porozumělo podle svých slov naprosto všemu novému učivu matematiky, 49 \% žáků uvádí, že porozuměli téměř všemu novému učivu matematiky, $35 \%$ pak spíše porozumělo a pouze 8 \% spíše neporozumělo novému učivu. ${ }^{21}$

Poslední otázka se zaměřila na psaní online testů z matematiky během učení se doma. 39 \% žáků souhlasí s psaním pouze tréninkových testů bez udělení známky, 59 \% se vyslovilo, že nechce při domácím učení psát žádné online testy z matematiky.

Z výsledků krátkého dotazníku vyplývá, že jsou žáci jak na nižším, tak i na vyšším gymnáziu schopni samostatně nebo s pomocí učitele procvičovat matematické učivo a také porozumět zcela novému učivu. Aplikaci učebna považují žáci za velmi vhodnou komunikační platformu pro vedení výuky v domácím prostředí a za praktický nástroj pro odevzdávání a kontrolu domácích úkolů. Za vhodné podpůrné prostředky při učení matematice doma považují žáci především učebnice, výuková videa a částečně také synchronní online výuku.

\section{Závěr}

Distanční výuku matematiky na ZŠ a SŠ nepovažujeme podle našich zkušeností za efektivnější než výuku kontaktní ve školním prostředí. Distanční výuka však skýtá metodicko-didaktický a komunikační potenciál pro organizaci

$20 \mathrm{~K}$ prezentaci např. $\mathrm{v}$ PowerPointu byly připojeny nahrávky se zvukovým záznamem komentáře učitele, který se žákům spustí po kliknutí na příslušný buton.

21 Jde opět spíše o subjektivní posouzení žáků svých dovedností a znalostí, které nebyly ověřeny adekvátními didaktickými testy. Podle našeho názoru žáci své dovednosti a znalosti často značně podceňují. 
a vedení řádné výuky ve škole. Př́kladem může být efektivní zadávání, odevzdávání a následná kontrola domácích úkolů z matematiky v prostředí Učebny. Tuto komunikační a výukovou platformu chceme nadále využívat i při řádné výuce matematiky.

\section{Literatura}

Kalhous, Z., \& Obst, O. (2002). Školní didaktika. Praha: Portál.

MŠMT (2020). Dotazy k aktuálním opatřením ke koronaviru. Dostupné z http://www.msmt.cz/ faq-nejcastejsi-dotazy-k-aktualnim-opatrenim-ke-koronaviru

Pavlas, T., Pražáková, D., Zatloukal, T., Andrys, O., Novosák, J., Folwarczny, R., Borkovcová, I., Modráček, Z., \& Chovancová, K. (2020). Vzdělávání na dálku v základních a středních školách. Tematická zpráva. Praha: ČŠI. Dostupné z https://www.csicr.cz/Csicr/media/ Prilohy/PDF_el__publikace/Tematick\%c3\%a9\%20zpr\%c3\%a1vy/Vzdelavani-na-dalku-vZS-a-SS-Tematicka-zprava.pdf

Petty, G. (2004). Moderní vyučování. Praha: Portál.

Průcha, J., Walterová, E., \& Mareš, J. (2003). Pedagogický slovník. Praha: Portál.

Smetáčková, I. (2014). Domácí př́íprava v matematice (na pozadí vztahu mezi rodinou a školou). Pedagogika, 64(2), 212-225.

\section{Autor}

PhDr. RNDr. Jan Fiala, Ph.D., Jihočeská univerzita v Českých Budějovicích, Ekonomická fakulta, Katedra aplikované matematiky a informatiky, Studentská 13, 37005 České Budějovice, e-mail: fiala@ef.jcu.cz 